\title{
RESULTS OF A HYDROGEOLOGICAL STUDY OF A PRECAMBRIAN KARST AQUIFER IN A SEMI-ARID REGION FROM MINAS GERAIS, BRAZIL
}

\author{
ADELBANI BRAZ DA SILVA*
}

\begin{abstract}
A Precambrian karst aquifer located in a semi-arid region in eastern central Brazil was studied to determine its hydrogeological characteristics. Several field methods were used, including environmental isotopes, artifical tracers, geophysical sensors, and satellite images. In addition, hydrochemical, hydroclimatological, geomorphological and piezometric data were collected. A two-dimensional, unsteady-state, finite-diference flow model was also employed. The transmissivity of the aquifer varied considerably from $5 \mathrm{~m}^{2} /$ day to $500 \mathrm{~m}^{2}$ /day with an average value of aproximately 40 $\mathrm{m}^{2} /$ day. The piezometric surface also varied with gradients on the order of 0.002 to 0.004 in the northern part of the aquifer and 0.003 to 0.005 in the southern portion. The lowest gradients $(0.0004)$ were found in the central region. The hydrochemical data showed that bicarbonate and calcium ions strongly influenced the electrical conductivity which was found to vary with the lithology of the aquifer. The small amounts of chlorides found were dependent on climatic conditions, while sulfates and hardness were found to vary in the same manner as electrical conductivity. The isotope concentrations had irregular distributions which indicated local recharge and flow zones and little dispersion in the aquifer. The most important result of this study was the identification of the most favorable locations for developing significant water supplies.
\end{abstract}

\begin{abstract}
RESUMO Um carste de uma região semi-árida no Brasil foi estudado com o objetivo de se conhecer as suas caracterf́sticas hidrogeológicas. Foram utilizados isótopos ambientais, traçadores artificiais, sensores geofísicos, imagens de satélite e estudos hidrogeoquímicos, hidroclimáticos, piezométricos, além de um mođelo matemático de simulação. A transmissivídade desse aquíf́rero varia muito: as áreas menos transmissoras têm valores da ordem de $5 \mathrm{~m} 2 /$ dia; áreas mais transmissoras podem atingir 500 $\mathrm{m}^{2} /$ dia. A transmissividade média é de $40 \mathrm{~m}^{2} /$ dia. A superff́cie piezométrica mostra duas elevaçóes; uma ao norte, com gradiente da ordem de 0,002 a 0,004 , e outra ao sul, com gradiente entre 0,003 a 0,005 . Os menores građientes são de aproximadamente 0,0004 e encontram-se na porção central da área. $O$ estudo hidroquímico mostrou que a condutividade elétrica varia com a litologia do aqǘffero $\mathrm{e}$ que os fons bicarbonato e cálcio são os que mais influenciam nesta variação. As pequenas quantidades de cloretos encontrados dependem das condiçōes climáticas, e o sulfato e a dureza apresentam variação semelhante à condutividade elétrica. A concentração isotópica tem distribuição irregular, o que indica recarga e fluxo locais e pouca đispersão da água. A interpretação dos dados permitiu identificar zonas com condiçð̃es hidrogeológicas favoráveis à explotação de águas subterrâneas.
\end{abstract}

INTRODUCTION A series of studies and hydrogeological research were made during a five-year period on a Precambrian semi-arid region called Jaiba, in the state of Minas Gerais, Brazil. The object of this work was to evaluate and to compare techniques of prospection and exploitation of groundwater in this type of aquifer and to obtain its hydrogeologic characteristics.

In addition to the traditional techniques, the following methods were applied: environmental isotopes; artificial tracers; geophysical sensors; satellite images; hydrochemical, hydroclimatic, geomorphological and piezometric studies; and a mathematical simulation model.

The main results of the study are given in this paper.

\section{GENERAL CHARACTERISTICS OF THE JAIBA} AREA The Jaíba area is about $5,150 \mathrm{~km}^{2}$ and is bordered on the west by the São Francisco River, on the east and north by the Verde Grande River and on the south by the Sabonetal Mountain. The Jaíba area is generally flat, with the highest topographical elevation equal to about $50 \mathrm{~m}$ above the aluvial plane of the São Francisco River ( $440 \mathrm{~m}$ altitu- de). To the south, the Sabonetal and Azul mountains rise to an altitude of 840 and $720 \mathrm{~m}$ respectively, and in the north, the Catarino Hill rises to $598 \mathrm{~m}$.

The São Francisco River has an average flow of 1,850 $\mathrm{m}^{3} / \mathrm{s}$, with a minimum of $225 \mathrm{~m}^{3} / \mathrm{s}$. The level of the São Francisco River creates a constant boundary condition for the Jarba aquifer. Floods up to $10,000 \mathrm{~m}^{3} / \mathrm{s}$ occur with a flood depth of $15 \mathrm{~m}$. On the other hand, the Verde Grande River is small and has an average flow of $14 \mathrm{~m}^{3} / \mathrm{s}$ at its southern point and $28 \mathrm{~m} / \mathrm{s}$ in the north, where it intersects the São Francisco River. The minimum flow is between 0.1 and $0.5 \mathrm{~m}^{3} / \mathrm{s}$. The other streams within the Jaiba area are intermittent.

The average rainfall is about $800 \mathrm{~mm} /$ year, the dry season being between July and September. The average annual temperature is $23.5^{\circ} \mathrm{C}$ with a variation between 17 to $33^{\circ} \mathrm{C}$ and a potential evapotranspiration demand of 1,300 $\mathrm{mm} /$ year. From a hydrometeorological balance, the net infiltration was calculated to be $35 \mathrm{~mm} /$ year, in general concentrated in January (the rainy season).

The Jaíba aquifer consists of a sequence of Precambrian limestone layers, called the Bambuí Group, that lies di\footnotetext{
* Instituto de Geociências da Universidade Federal de Minas Gerais e Fundação Centro Tecnológico de Minas Gerais, Cx. Postal 2306, CEP
30 000, Belo Horizonte, MG, BRASIL.
} 
rectly over a Precambrian gneiss basement. The limestone is covered, in a large area, by a layer of Tertiary-Quaternary detrital sediments and by recent alluvial deposits along the Săo Francisco and Verde Grande rivers.

From a structural point of view, the Jafba area corresponds to a block that has been lowered by a fault that runs parallel to the São Francisco River. The limestone beds have a subhorizontal dip and are crossed by large fractures with strikes of $\mathrm{N} 40-50^{\circ} \mathrm{W}$ and $\mathrm{N} 30-40^{\circ} \mathrm{E}$. Cainozoic karstification produced a typical topography, being characterized by a high density of sinkhole and some oriented longitudinal fractures. The surface lithological and structural properties of the Jaiba area have been thoroughly studied and mapped to a scale $1: 100,000$ by Costa (1978). However, little geologic information exists about the subsurface properties of the Jaiba aquifer.

The thickness of the limestone sequences and the depth of the crystalline basement are not known. The depth of karstification is, in general, less than $100 \mathrm{~m}$, with most of the fissures about $30-40 \mathrm{~m}$ in depth. The fissures lie slightly above the level of the São Francisco River, this being confirmed by isotopic well logs (bromine-82) in 42 wells (Plata et al. 1980); the layer of Terciary-Quaternary detrital sediment is very thin, with an average thickness of $15 \mathrm{~m}$ and a maximum thickness of $65 \mathrm{~m}$. This has been confirmed by resistivity and from well logs (Escodino \& Silva 1981).

HYDROLOGIC PARAMETERS Transmissivity data from the aquifer were obtained through 60 pumping tests, 55 specific capacity tests, and 10 chemical and radioactive tracer dilution tests.

The pumping tests could only be used to compute a rough estimate of the transmissivities because of: the presence of fissures, the different potentials in the fissures (ve rified in the tracer tests), the nonradial flow and heterogeneous conditions of the aquifer. The specific capacity of a well is greatly influenced by well losses, particularly when the well water drains from small and short fractures. In this case, the specific capacity method gives a minimum local transmissivity value. The transmissivities varied greatly, from a low value of 5 to $10 \mathrm{~m}^{2} /$ day, to a high value of $500 \mathrm{~m}^{2} /$ day, with an average transmissivity about 30 to 50 $\mathrm{m}^{2} /$ day. In the upper portion of the aquifer (the karst region), the transmissivity ranges between 100 and 300 $\mathrm{m}^{2} /$ day.

Due to noise in the short term drawdown data, only the long term drawdown data were used to compute the storage coefficient, using the hydrogram method. The storage con efficient using discharge data from Verde Grande River (upstream, near the village of Colônia do Jaíba) was to be between 0.01 and 0.001 . However, a study of the fracture frequencies by the radioactive tracer method gave a much higher storage coefficient than the one obtained by means of the by than the one obtained by means of the hydrogram method.

Finally, a hydrogram method, using the water level response to rain in 36 wells, gave a storage coefficient that ranged between 0.005 and 0.02 . From these same 36 wells, it was also possible to compute the hydraulic diffusivity (T/S), which varied between 13 and $700 \times 10^{3} \mathrm{~m}^{2} /$ day.

The results of the above tests are listed in Tab. 1 .

WATER TABLE The variations in the water table were measured monthly in a network of 98 observation points between October, 1977 to May, 1979. After 1979, the observation network was reduced to 25 points and thesewere measured until August, 1981. Water level recorders were installed in 6 additional wells from October, 1977 to $\mathrm{Au}$ gust, 1981 .

The water table contour map of the Jaiba area in the end of the rainy season of 1981 is shown in Fig. 1, where there are two zones with large water table gradients located at the Sabonetal Mt, and the Caratino Hill regions. Between these two zones, the water table gradient is very flat. Also note that there is no water table divide between the Verde Grande and São Francisco rivers. This indicates that the Verde Grande River is not hydrologically connected to the Jarba aquifer, however water can pass under the Verde Grande River.

Various stream-gauging stations were installed in the Verde Grande River in order to measure the flow rate during 1.978 and 1979. Custódio et al. (1981) showed that in the dry season the Verde Grande River is effluent until Colonia do Jaiba but, farther than this, it neither gains nor loses water until the Verde Grande joins the São Francisco River.

Hydrographs from the water level recorders between 1977 and 1979 (20 months in total) showed two regions in the Jarba aquifer with large piezometric variations (a maximum of $15 \mathrm{~m}$ ) and the rest of the Jaíba area with small variations (see Fig. 1). In the northern region of the Jaiba aquifer (at Catarino Hill) the piezometric gradient was around 0.002 to 0.004 and to the south (at Sabonetal Mt.) a gradient of 0.003 to 0.005 . The above two locations represent recharge areas with low vertical permeabilities. In the

Table 1 - Transmissivity and storage coefficient of the Jaiba Aquifer

\begin{tabular}{|c|c|c|c|c|c|c|}
\hline \multirow[t]{2}{*}{ Zone } & \multicolumn{4}{|c|}{$\begin{array}{c}\text { Transmissivity } \\
\mathrm{T}\left(\mathrm{m}^{2} / \mathrm{d}\right)\end{array}$} & \multirow{2}{*}{\multicolumn{2}{|c|}{$\frac{\begin{array}{c}\text { Storage } \\
\text { Coefficient (S) }\end{array}}{\text { Range }}$}} \\
\hline & Average & & Range & & & \\
\hline $\begin{array}{l}\text { Sabonetal Mt. to Colônia do Jafba } \\
\text { Sabonetal Mt. W zone } \\
\text { Colônia do Jaba, distant zone } \\
\text { Colônia do Jaba, near zone } \\
\text { Central plain, E zone } \\
\text { Central plain, W zone } \\
\text { Catarino Hill, high zone } \\
\text { Catarino Hill, north plain } \\
\text { São Francisco River, flood plain }\end{array}$ & $\begin{array}{r}25 \\
200 \\
70 \\
500 \\
100 \\
1,000 \\
20 \\
100 \\
150\end{array}$ & from & $\begin{array}{rr}15 & \text { to } \\
80 & \\
40 & \\
40 & 1 \\
50 & \\
300 & 2 \\
5 & \\
20 & \\
50 & \end{array}$ & $\begin{array}{r}40 \\
300 \\
100 \\
1,000 \\
500 \\
2,000 \\
50 \\
300 \\
300\end{array}$ & $\begin{array}{r}\text { from } 0.002 \\
0.005 \\
0.002 \\
0.010 \\
0.010 \\
0.020 \\
0.001 \\
0.010 \\
0.020\end{array}$ & 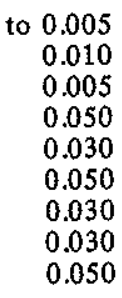 \\
\hline
\end{tabular}




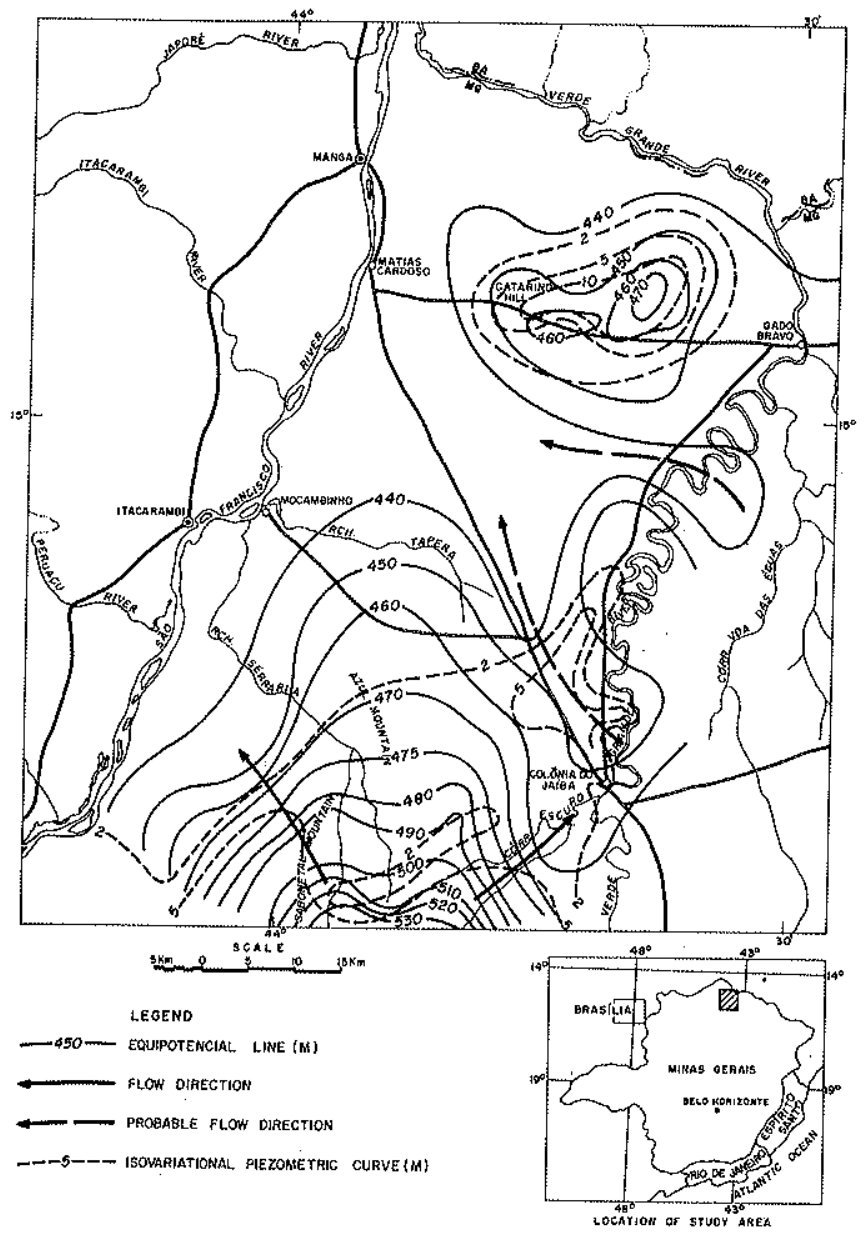

Figure 1 - Water-table contour map for the end of the rainy season (1981)

central zone of the Jaíba area, the piezometric gradient was the order of 0.0004 . However the storage coefficient is greater in the central region than in other areas.

HYDROCHEMICAL STUDY Water samples were collected during four dry and rainy seasons. A total of 427 sam. ples of groundwater and 254 surface-water samples were analysed.

Chemical analysis showed that the chemical composition of the water in the São Francisco River does not depend on the groundwater. In the dry season the elevated concentration of $\mathrm{HCO}_{3}^{-}$in the Verde Grande River between the villages of Colônia do Jaíba and Gado Bravo indicated that this river was chemically similar to that of the groundwater (Tab. 2). During the rainy season there was a notable decrease in the total dissolved solids downstream of Colônia do Jaíba, indicating a strong groundwater contribution to the river. However, the chloride concentration was much higher than that in the rainy water.

Using a modified stiff diagram map it was possible to identify areas with equal chemical facies and to make groupings according to the method of Schoeller, which orders the concentrations of the anions and cations (Custódio \& Llamas 1976).

A study of the spatial distribution of the chemical characteristics of the groundwater showed: a) the electrical conductivity varied with the lithology of the aquifer and bicarbonate and calcium ions have the greatest influence on this variations (Fig. 2); b) the hardness is similar to the electrical conductivity and the alkaline-earth metals are the dominant cations (where elevated concentrations are dominated by limestone); c) the chloride concentrations are low and depend on climatic conditions (the concentrations range between 40 and $50 \mathrm{ppm}$ at Sabonetal Mt. and Caterino Hill and are $80 \mathrm{ppm}$ near Colónia do Jarba); d) the zones of high chloride concentrations do not necessarily coincide with high electrical conductivity; e) the distribution of chlorides shows that there are two circulation paths, one along the Serraria stream to the São Francisco River and the other between Colônia do Jarba to Mocambinho village (Silva et al. 1982); f) the sulfate concentration is normally low and is parallel to the electrical conductivity and hardness (suggesting that the same phenomenon that controls the variation in the electrical conductivity and hardness controls also the variation in the sulfate);g) the $\mathrm{rSO}_{4} / \mathrm{rCl}$ ratio is similar to the hardness; $h$ ) the $\mathrm{rNa} / \mathrm{rCl}$ ratio can be used to show that the solution preferentially dissolves $\mathrm{Ca}^{2+}$ and $\mathrm{Na}^{+}$.

A chloride balance was used to calculate the infiltration coefficient of the rain water into the aquifer. The infiltration coefficient was estimated supposing that the major part of the $\mathrm{Cl}^{-}$ions of the groundwater came from the atmosphere (Tab. 3).

ENVIRONMENTAL ISOTOPES Water samples were analysed for natural isotopes [oxygen-18 (0-18), deuterium (D) and tritium (T)]; 127 samples where subdivided as follows: 63 groundwater and 11 surface water samples were analysed for 0.18 and $D ; 49$ groundwater and 4 surface water samples were analysed for $\mathrm{T}$.

Table 2-Chemical characteristics of the water of the Verde Grande River

The most representative range of chemical variation (ppm)

\begin{tabular}{|c|c|c|c|c|c|c|c|c|}
\hline Gauge & $\mathrm{Ca}^{2+}$ & $\mathrm{Mg}^{2+}$ & $\mathrm{Na}^{+}$ & $\mathrm{Cl}^{-}$ & $\mathrm{SO}_{4}^{2-}$ & $\mathrm{CO}_{3} \mathrm{H}^{-}$ & $\mathrm{rSO}_{4} / \mathrm{rCl}$ & $(\mathrm{rCl}-\mathrm{rNa}) / \mathrm{rCl}$ \\
\hline $\begin{array}{l}\text { VG-11 } \\
\text { VG-04 } \\
\text { VG-14 } \\
\text { VG-12 }\end{array}$ & $\begin{array}{l}40-75 \\
40-75 \\
40-75 \\
35-65\end{array}$ & $\begin{array}{l}5-7 \\
4-8 \\
5-9 \\
6-8\end{array}$ & $\begin{array}{r}8-14 \\
7-10 \\
10-13 \\
9-15\end{array}$ & $\begin{array}{r}10-15 \\
9-15 \\
10-15 \\
11-18 \\
\end{array}$ & $\begin{array}{r}11-20 \\
9-20 \\
13-18 \\
8-13\end{array}$ & $\begin{array}{r}150-300 \\
130-220 \\
150-250 \\
80-200\end{array}$ & $\begin{array}{c}1 \\
1 \\
0 / 21 \\
1\end{array}$ & $\begin{array}{r}0 /(-) \\
(-) \\
(-) \\
(-)\end{array}$ \\
\hline Groundwater & $45-80$ & $4-8$ & $2-5$ & $30-40$ & $25-30$ & $300-400$ & - & - \\
\hline
\end{tabular}



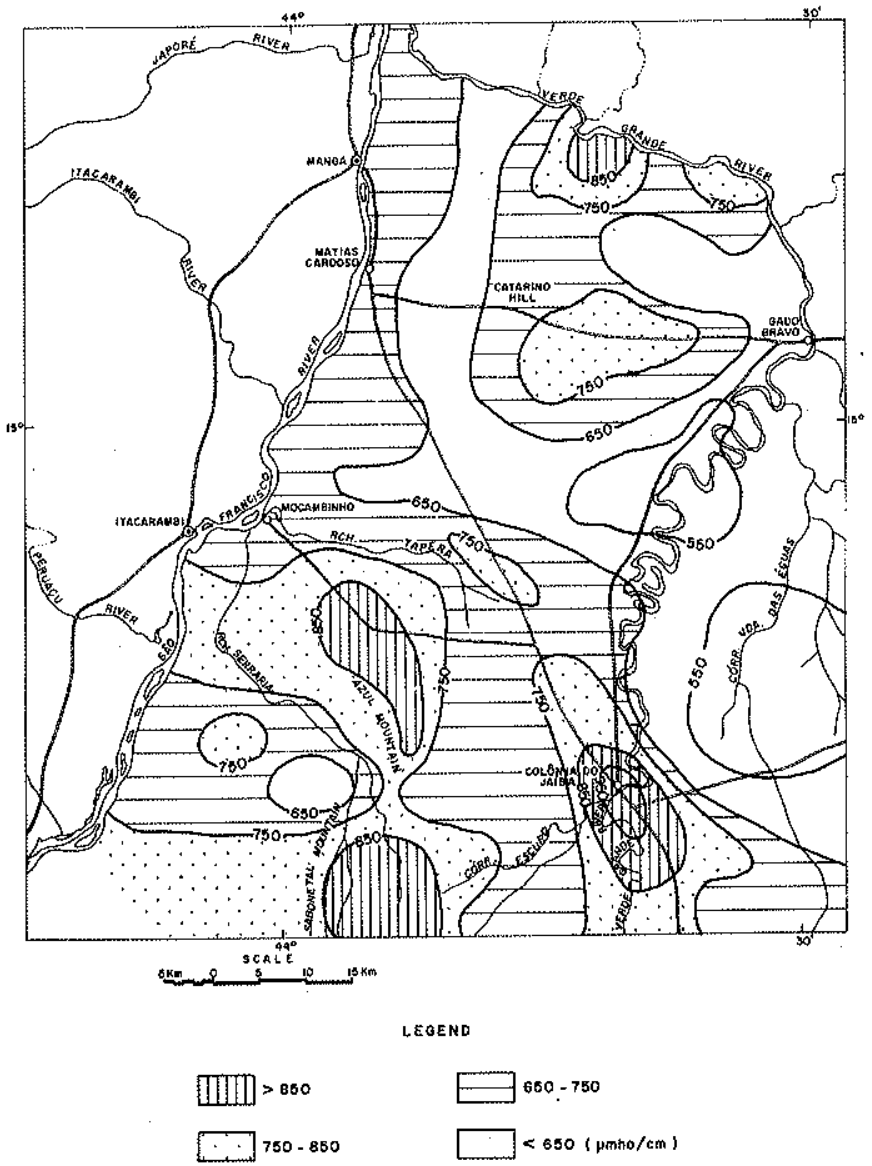

Figure 2 - Spatial distribution of the electrical conductivity

The following conclusions were obtained from the T, D and 0-18 analyses (Plata et al. 1980, Custódio et al 1981): a) evaporation of the rain water is negligible, except in a few localized areas (this allows us to do a chloride balance); b) the isotope concentrations have an irregular distribution which indicates that the recharge and flow are local and that the groundwater exhibits little dispersion; c) the triti. um analysis confirmed the deuterium and oxygen-18 analysis (Fig. 3); d) the tritium concentraion appears to decrease with the depth of the groundwater sample [the tritium concentration follows the relation: $T=5.5 \times \ln (\mathrm{h})+$

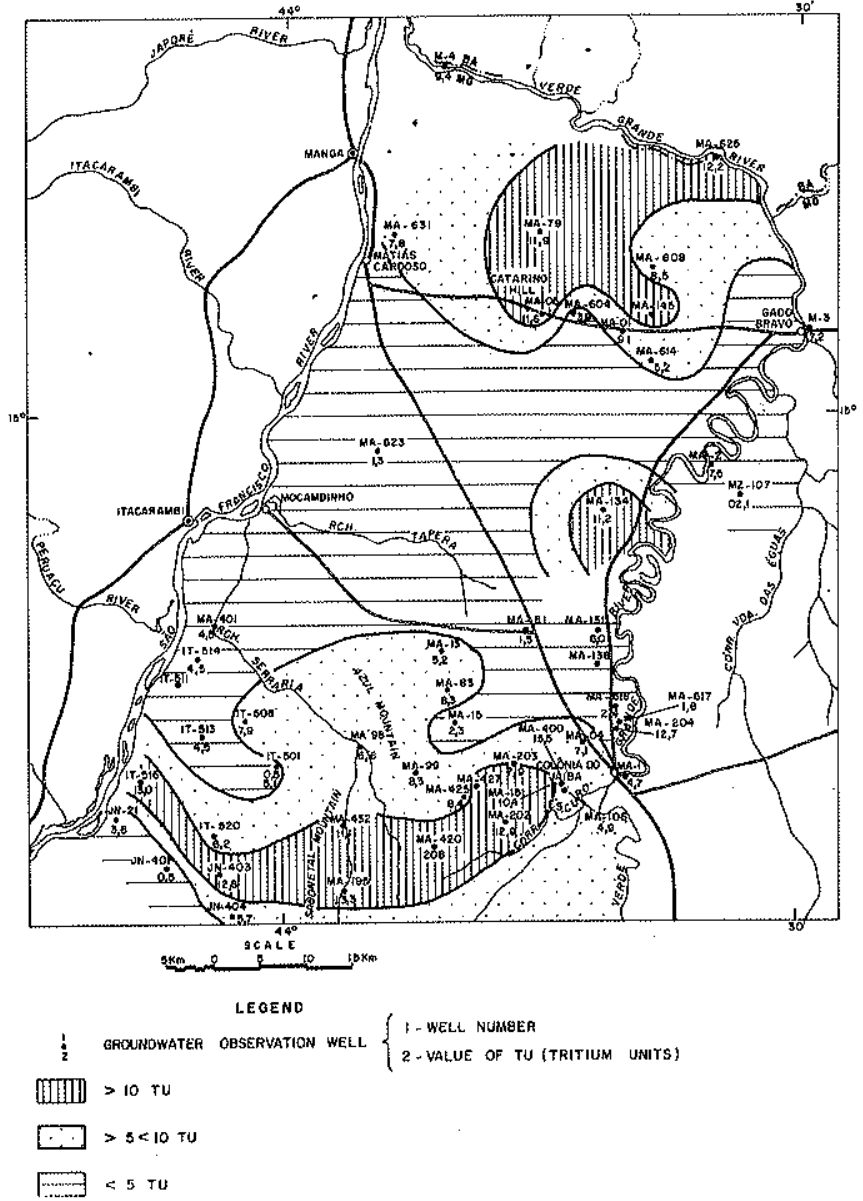

Figure 3 - Distribution of the results of the tritium analyses

28.1, where $\mathrm{T}$ is in $\mathrm{TU}$ (tritium units), $\mathrm{h}$ (depth) in meters and $\ell n$ indicates natural logarithmn ; $\mathrm{e}$ ) the tritium analysis indicate that the aquifer is well mixed and has an average residence time of 50 years. The highest residence times were found in the west Sabonetal Mt. and Colônia do Jaíba areas ( 80 to 100 years), the $\mathrm{N}-\mathrm{NW}$ sector (160 years) and the central zone (200 years). The smallest residence times were found in the central Sabonetal Mt. and the E-NE area (20 years), Catarino Hill (6 to 20 years) and north plain (910 years). These last areas have the smallest storage coefficients and the greatest circulation.

Table 3 - Average annual infiltration coefficient of the rain water

\begin{tabular}{|c|c|c|c|c|c|}
\hline \multirow{2}{*}{ Zone * } & \multirow{2}{*}{$\begin{array}{l}\text { Concentration } \\
\text { of } \mathrm{Cl}^{-} \text {in } \\
\text { Groundwater } \\
\text { (ppm) }\end{array}$} & \multicolumn{2}{|c|}{$\begin{array}{l}\text { Infiltration } \\
\text { Coefficient }(I)^{* *}\end{array}$} & \multicolumn{2}{|c|}{$\begin{array}{c}\text { Deep Infiltration } \\
\text { for } P-E=800 \mathrm{~mm} / \mathrm{yr}\end{array}$} \\
\hline & & Average & Extreme & AVG & Range \\
\hline $\begin{array}{l}\text { Flood plain of the São Francisco River } \\
\text { Drainage area of the Serraria stream } \\
\text { Sabonetal Mt. high zone } \\
\text { Sabonetal and Azul Mts. North } \\
\text { Colônia do Ja ba } \\
\text { Central plain } \\
\text { North plain }\end{array}$ & $\begin{array}{l}10 \\
40 \\
10 \\
15 \\
15 \\
45(?) \\
5(?)\end{array}$ & $\begin{array}{l}0.020 \\
0.005 \\
0.020 \\
0.015 \\
0.015 \\
0.004 \\
0.040\end{array}$ & $\begin{array}{l}0.010-0.030 \\
0.002-0.007 \\
0.010-0.030 \\
0.007-0.020 \\
0.007-0.020 \\
0.002-0.006 \\
0.040-0.060\end{array}$ & $\begin{array}{r}16 \\
4 \\
16 \\
12 \\
12 \\
3 \\
24\end{array}$ & $\begin{array}{l}(8 \text { to } 24) \\
(2 \text { to } 6) \\
(8 \text { to } 24) \\
(6 \text { to } 16) \\
(6 \text { to } 16) \\
(2 \text { to } 5) \\
(12 \text { to } 48)\end{array}$ \\
\hline
\end{tabular}

* Range of the rain $\mathrm{Cl}^{-}$is from 0.10 to $0.30 \mathrm{ppm}$

* The infiltration coefficient is defined as the percent of precipitation which actually reaches the aquifer 

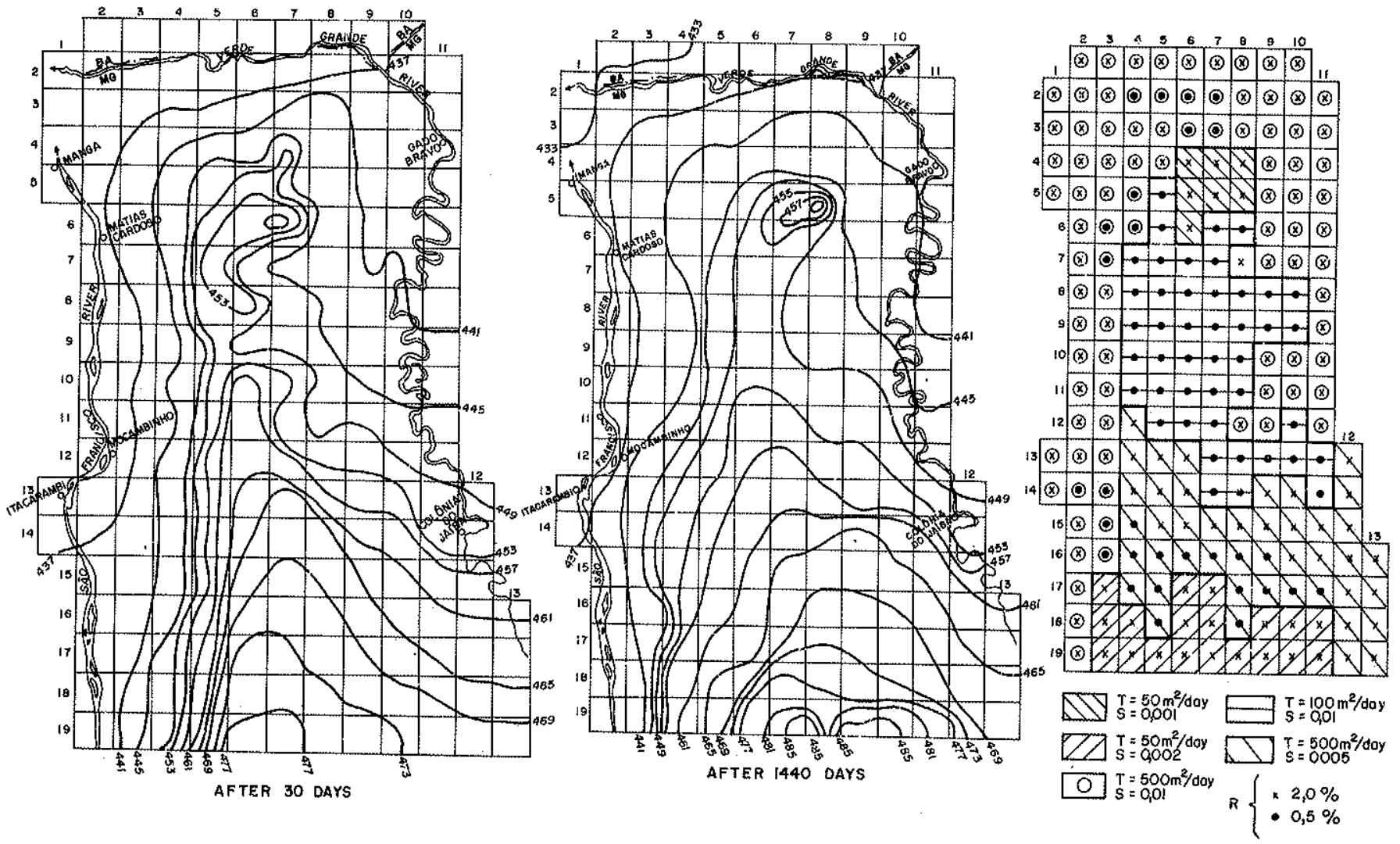

Figure 4 - Finite difference grid used in the prickett and lonnquist model

MATHEMATICAL MODEL The objective of the simulation model was to integrate the different data into a coherent system which would be able to reproduce the observed data and hence to verify the methodology applied to this study. The Prickett \& Lonnquist (1971) finite difference model was used. A grid with 13 columns and 19 rows was used, with a total of 206 , with $5 \times 5 \mathrm{~km}^{2}$ each elements (Fig. 4). The São Francisco River was treated as a constant head boundary condition. The observed piezometric surface at the end of the 1977 dry season was used to specify the initial condition.

The simulations showed that the water accumulated in the aquifer after two to four years created a steady state piezometric surface with gradients greater than those observed (Fig. 4). The simulation showed that it was more reasonable to have small values of recharge (1 to $2 \%$ ) and large values of transmissivity ( $500 \mathrm{~m}^{2} /$ day), specially in the central zone (Cruz \& Silva 1980). The hydrologic balance was approximately in equilibrium after the fourth year of simu. lation and revealed that the aquifer had a high flood control capacity. This was because the aquifer absorbed infiltrating water during the first five months of the hydrologic cycle and slowly liberated it later in the year.

HYDROGEOLOGIC CHARACTERISTICS OF THE AQUIFER An interpretation of the hydrologic, hydrochemical, and environmental isotopes data and the results of the simulation model identified six zones with different hydrogeologic characteristcs (Fig. 5): a) flood plain of the Säo Francisco River - this zone is influenced by the variation of the river level and has a width of about 2 to $5 \mathrm{~km} ; b$ )

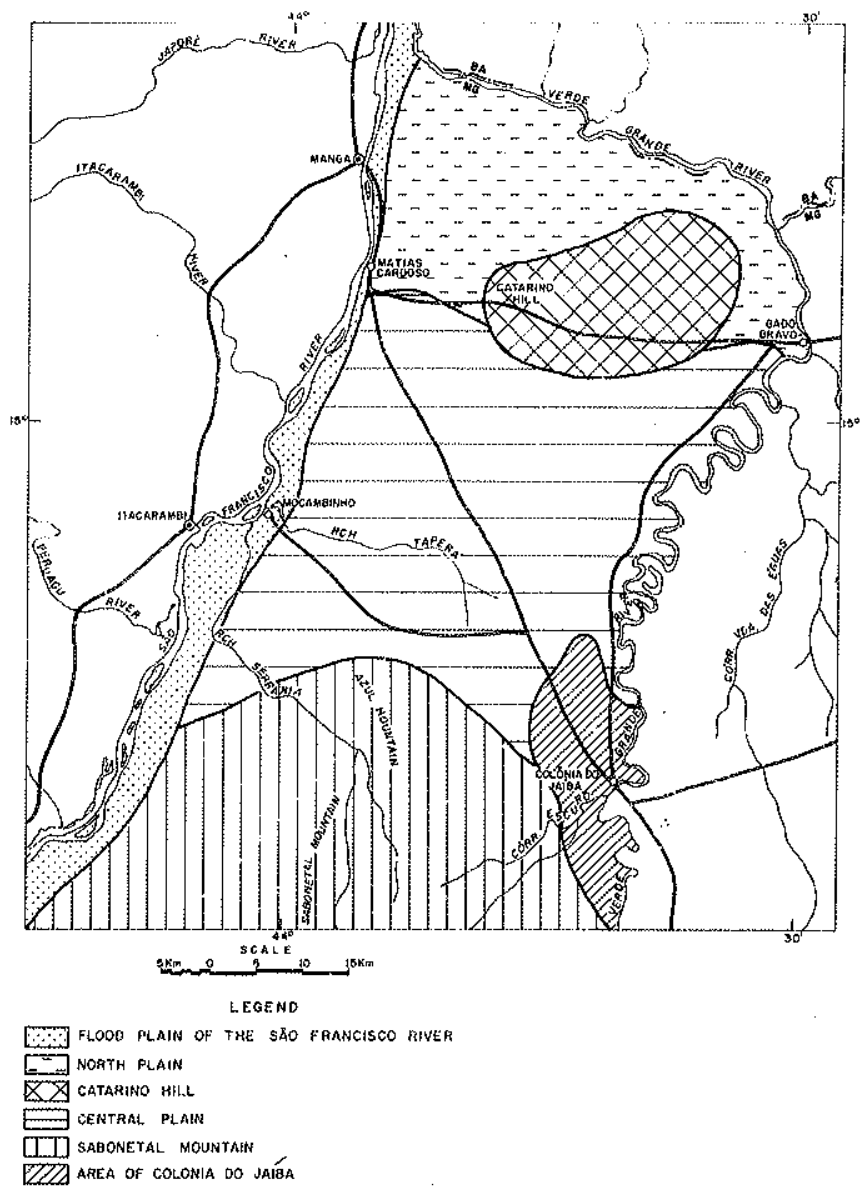

Figure 5 - Delineation of the Jaiba Karst aquifer 
north plain - this zone has a moderate hydraulic diffusivity that stores water during the rainy season. This stored water is then discharged into the Verde Grande River and São Francisco River with gradients less than 0.0004 ; c) Catarino Hill - has moderate very diffuse recharge, and a very low storage coefficient. The recharge water is rapidly transferred to the north and central plains; d) central plain this zone probably has the greatest reserve of groundwater and highest transmissivities. It discharges water to the São Francisco River and it can receive water from the Verde Grande River. There appears to be two preferential circulation zones; one that begins near Colonia do Jarba, and the other, upgradients of the confluence of the Verde Grande River with the Gurutuba River; e) Sabonetal Mt. - has moderate and very diffuse recharge, with a reduced storage coefficient and little hydrologic significance. It discharges to the E-NE (colônia do Jaíba) and to the NW (São Francisco); f) area of Colonia do Jaiba - it is a very heterogeneous zone. There appears to exist a preferential permeable zone to the NW that conducts water to the central plain. It can receive water from the southern side of the Sabonetal Mt. and perhaps from the Verde Grande River.

Acknowledgements The author wishes to thank Dr. Emúlio Custódio, Dr. Antônio Plata Bedmar, Dr. Paulo Cyro Baptista Escodino and Dr. Waldemir Barbosa da Cruz for their participation in this work and for their valuable advices. This study become possible through the financial support of the Conselho Nacional de Desenvolvimento $\mathrm{Ci}$ entífico e Tecnológico - CNPq.

\section{REFERENCES}

COSTA; P.C.G. - 1978 - Geologia das folhas de Januária, Mata do Jaíba, Japoré e Manga, Minas Gerais, In: CONGR. BRAS. GEOL., 30, Recife, 1978. Anais. . Recife, SBG v. 1, p. 83-87.

CRUZ, W.B. \& SILVA, A.B. - 1980 - Modelo de simulaç̃o digital do aquífíforo cárstico da região do Jaíba, norte de Minas Gerais. In: CONGR. BRAS. ÁGUAS SUBTERRÂNEAS, 1, Recife, 1980. Anais... Recife, ABAS, p. 359-374.

CUSTODIO, E. \& LLAMAS, M.R. - 1976 - Hidrologla Subterránea. Barcelona, Ed. Omego, v. 1,2290 p.

CUSTÓDIO, E.; CRUZ, W.B.; SILVA, A.B.; ESCODINO, P.C.B. 1981 - Datos de base para un modelo matemático de simulación del area de Jaíba - rio São Francisco (Minas Gerais, Brasil). In: ASAMBLEA NACIONAL DE GEODESIA Y GEOFISICA, 4, Zaragoza, 1981. Anais. .. Zaragoza v. 1, p. 1-19.

ESCODINO, P.C.B. \& SILVA, A.B. - 1981 - Aplicação de métodos de prospeç̧ão geo-elétrica na pesquisa de aqǘf́cto cárstico. Rev.
Min e Metal, Rio de Janeiro, XVL(432): 16-21.

PLATA, A.; SILVA, A.B.; ESCONDINO, P.C.B. - 1980 - Perfilagem de pocos tubulares utilizando se isótopos artificiais. In CONGR. BRAS. ÄGUAS SUBTERRĀNEAS, 1, Recife, 1980. Anais. .. Recife, ABAS. p. 131-146.

PLATA, A. \& SILVA, A.B. - 1980 - Estudio isotópico de un acuifero cártico in Minas Gerais, Brasil. In: INTERAMERICAN SYMPOSIUM ON ISOTOPE HYDROLOGY, 1, Bogotá, 1980. Proceedings... Bogotá. v. 1, p. 337-357.

PRICKETT, T.A. \& LONNOUIST, C.G. - 1971 - Selected digital computer techniques for groundqater resources evaluation. Illinois State Water Survey. 66 p. (Bull. 55).

MANUSCRITO Recebido em 14 de maio de 1984 Revisão aceita em 05 de dezembro de 1984. 